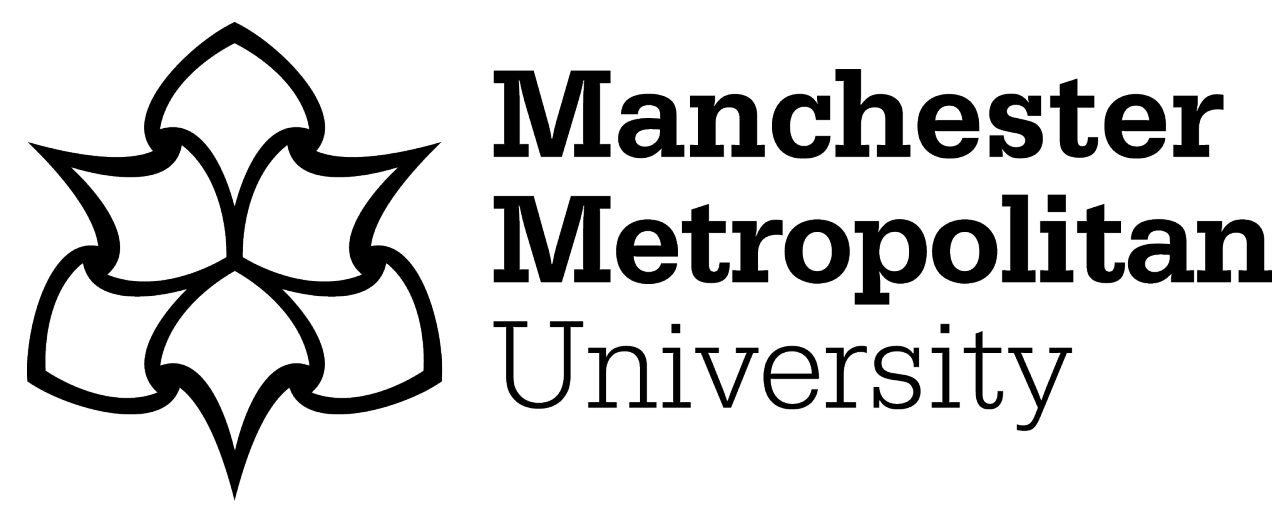

Barlow, J, França, F, Gardner, TA, Hicks, CC, Lennox, GD, Berenguer, E, Castello, L, Economo, EP, Ferreira, J, Guénard, B, Gontijo Leal, C, Isaac, V, Lees, Alexander, Parr, CL, Wilson, SK, Young, PJ and Graham, NAJ (2018) The future of hyperdiverse tropical ecosystems. Nature, 559. p. 517. ISSN 0028-0836

Downloaded from: https://e-space.mmu.ac.uk/621350/

Version: Submitted Version

Publisher: Springer Nature

DOI: https://doi.org/10.1038/s41586-018-0301-1

Please cite the published version 


\section{The future of hyperdiverse tropical ecosystems}

Jos Barlow $^{1 *}$, Filipe França ${ }^{1,2}$, Toby A. Gardner ${ }^{3}$, Christina C. Hicks ${ }^{1}$, Gareth D. Lennox ${ }^{1}$, Erika Berenguer ${ }^{1,4}$, Leandro Castello $^{5}$, Evan P. Economo ${ }^{6}$, Joice Ferreira ${ }^{2}$, Benoit Guénard ${ }^{7}$, Cecília Gontijo Leal ${ }^{8}$, Victoria Isaac ${ }^{9}$, Alexander C. Lees ${ }^{10}$, Catherine L. Parr ${ }^{11,12,13}$, Shaun K. Wilson ${ }^{14,15}$, Paul J. Young ${ }^{1} \&$ Nicholas A. J. Graham ${ }^{1}$

The tropics contain the overwhelming majority of Earth's biodiversity: their terrestrial, freshwater and marine ecosystems hold more than three-quarters of all species, including almost all shallow-water corals and over $90 \%$ of terrestrial birds. However, tropical ecosystems are also subject to pervasive and interacting stressors, such as deforestation, overfishing and climate change, and they are set within a socio-economic context that includes growing pressure from an increasingly globalized world, larger and more affluent tropical populations, and weak governance and response capacities. Concerted local, national and international actions are urgently required to prevent a collapse of tropical biodiversity.

$\mathrm{T}$ he tropics hold a disproportionate amount of global biological diversity and are key to meeting the international community's aims of socially just sustainable development and effective biodiversity conservation ${ }^{1}$. Yet, tropical ecosystems are undergoing rapid environmental, socio-economic and demographic change ${ }^{2}$, often driven by forces originating in extra-tropical developed countries. The scale of these changes is unprecedented, and decisions implemented in the coming decades will define the future sustainability of the tropics.

Guiding these decisions depends on understanding the diversity and vulnerability of the four major tropical ecosystems: the forests and mesic savannahs that cover most of the terrestrial tropics, the extensive freshwater systems that receive half of the world's rainfall and the shallow-water coral reefs distributed along $150,000 \mathrm{~km}$ of coastline (Fig. 1). Here we quantify and review the global importance of tropical biodiversity, evaluate the vulnerability of tropical ecosystems to proximate stressors and assess whether global and regional socio-economic changes will exacerbate or ameliorate biodiversity loss. We then examine the effectiveness of conservation approaches and highlight the scientific advances required to support a sustainable tropical future.

\section{The global importance of tropical ecosystems}

Over evolutionary time, the tropics have acted as both a source of and a refuge for extra-tropical terrestrial and marine species ${ }^{3,4}$; but just how diverse and irreplaceable are the tropics today? The increase in species richness from polar to tropical regions, known as the latitudinal diversity gradient, is found across a wide range of taxa and biomes. As a result of this gradient, tropical latitudes - which cover just $40 \%$ of the Earth's surface - hold a startling proportion of the planet's species: our assessment reveals that almost all shallow-water zooxanthellae corals, $91 \%$ of terrestrial birds, and over $75 \%$ of amphibians, terrestrial mammals, freshwater fish, ants, flowering plants and marine fish have ranges that intersect tropical latitudes (Fig. 2a). For birds, the importance of the tropics extends far beyond 23.5 degrees of latitude, given that almost half of all Nearctic species migrate to the Neotropics ${ }^{5}$ and over 2 billion individual passerines and near-passerines cross the Sahara each autumn ${ }^{6}$. Moreover, a disproportionate number of species are endemic to the tropics. For example, there are more than six times as many endemic terrestrial bird species in the tropics as in temperate regions (Fig. 2a). Tropical zones are less important for marine mammals and birds, which peak in diversity at mid-latitudes ${ }^{7,8}$. Nonetheless, more than $55 \%$ of these species use the tropics (Fig. 2a).

Overall, $78 \%$ of species across the ten taxa that we assessed occurred within tropical latitudes, but incomplete taxonomic inventories mean that this is almost certainly an underestimate ${ }^{9}$. Between 15,000 and 19,000 new species are described annually ${ }^{10}$, and the majority of recently described terrestrial vertebrates ${ }^{11}$ or predicted discoveries of invertebrates ${ }^{12}$ are from the tropics. Even terrestrial mammals are still being discovered at a rate of about 25 species a year, with the highest numbers in the Neo- and Afrotropics ${ }^{13}$. Shortfalls in species descriptions for other taxa are often far greater. For example, only 70,000 of an estimated 830,000 multicellular plants and animals have been named on coral reefs ${ }^{14}$, and although approximately 500 spider species are described each year, this is a tiny fraction of the estimated 150,000 undescribed tropical species ${ }^{15}$.

Tropical taxonomic shortfalls are further compounded by a suite of systematic sampling biases. These include undersampling when compared with temperate regions ${ }^{16}$, the spatial aggregation of sampling effort around coastal areas ${ }^{17}$, roads, rivers, urban settlements and highprofile research stations ${ }^{18}$, biases in favour of dry-season sampling when many invertebrate taxa are least abundant ${ }^{19}$, and the paucity of samples from ecosystems that are harder to access, such as mesophotic and rariphotic reefs ${ }^{20}$. The biological diversity of the tropics is

\footnotetext{
${ }^{1}$ Lancaster Environment Centre, Lancaster University, Lancaster, UK. ${ }^{2}$ Embrapa Amazônia Oriental, Belém, Brazil. ${ }^{3}$ Stockholm Environment Institute, Stockholm, Sweden. ${ }^{4}$ Environmental Change Institute, University of Oxford, Oxford, UK. ${ }^{5}$ Department of Fish and Wildlife Conservation, Virginia Tech, Blacksburg, VA, USA. ${ }^{6}$ Biodiversity and Biocomplexity Unit, Okinawa Institute of Science and Technology Graduate University, Onna, Japan. ${ }^{7}$ School of Biological Sciences, The University of Hong Kong, Hong Kong, China. ${ }^{8}$ Museu Paraense Emílio Goeldi, Belém, Brazil. ${ }^{9}$ Universidade Federal do Pará, Belém, Brazil. ${ }^{10}$ School of Science and the Environment, Manchester Metropolitan University, Manchester, UK. ${ }^{11}$ School of Environmental Sciences, University of Liverpool, Liverpool, UK. ${ }^{12}$ University of Pretoria, Pretoria, South Africa. ${ }^{13}$ University of Witwatersrand, Johannesburg, South Africa. ${ }^{14}$ Marine Science Program, Department of Biodiversity, Conservation and Attractions, Kensington, Western, Australia. ${ }^{15}$ Oceans Institute, University of Western Australia, Crawley, Western Australia, Australia *e-mail: josbarlow@gmail.com
} 

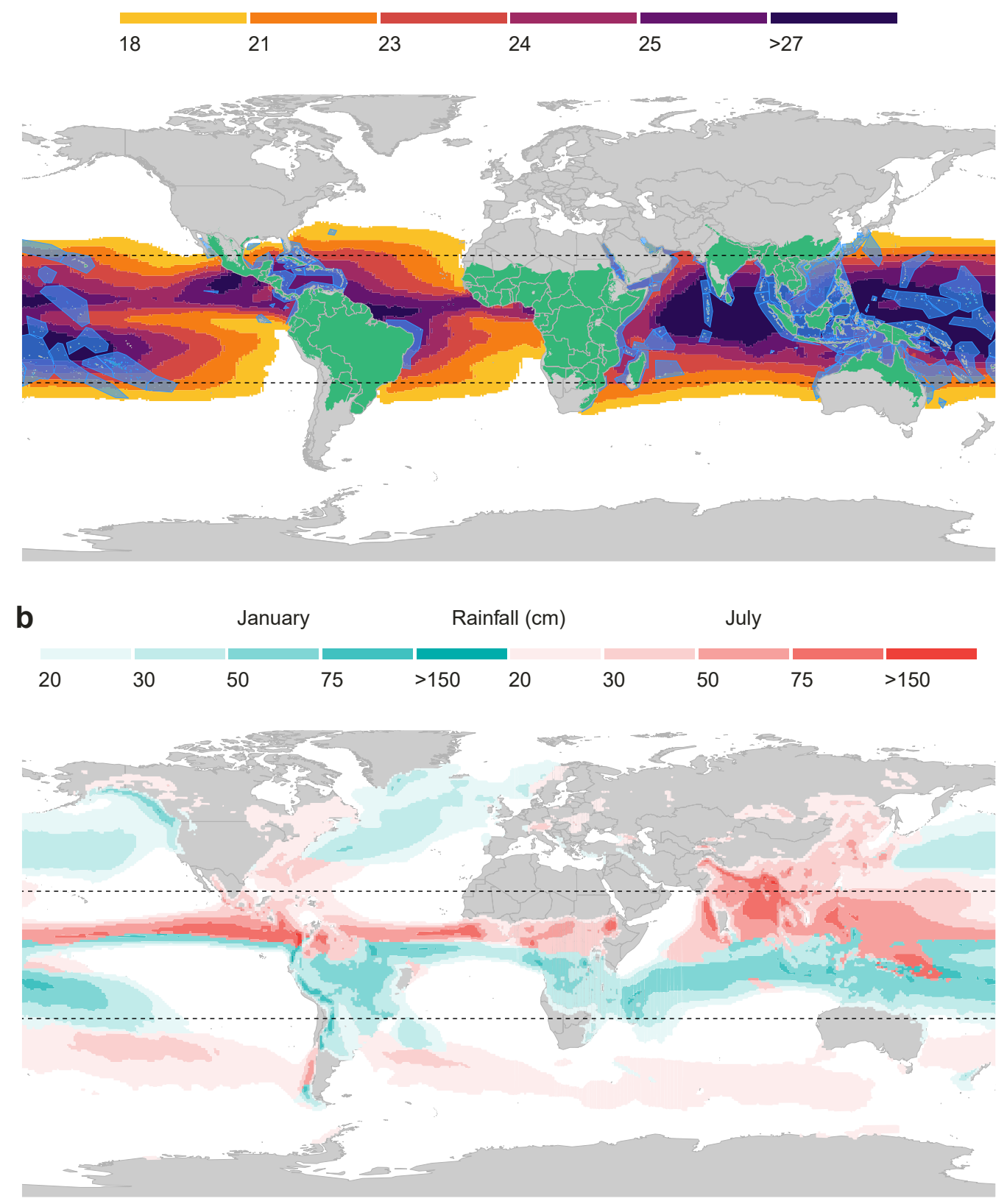

Fig. 1 The tropical biosphere. a, Tropical terrestrial and marine biomes. The tropical terrestrial biome (green) was defined as all tropical mesic ecoregions ${ }^{163}$ These ecoregions span $82 \%$ of the 50 million $\mathrm{km}^{2}$ of land between $23.5^{\circ} \mathrm{N}$ and $23.5^{\circ} \mathrm{S}$, but extend into the subtropics in some areas. The tropical marine biome was defined by the 1988-2018 mean minimum monthly $18 \mathrm{C}$ sea-surface isotherm. This isotherm bounds the latitudinal extent of shallow-water coral-forming ecoregions (blue) ${ }^{164}$. b. The intertropical convergence zone (ITCZ). The ITCZ was defined as regions that received a mid-summer (January (turquoise colour gradient) or July (red colour gradient)) mean monthly total rainfall of $>20 \mathrm{~cm}$, for the period 1979-2017. Where both January and July had rainfall of $>20 \mathrm{~cm}$, we show the measurement from the month with the largest total. The ITCZ is a strong predictor of the distribution of the tropical terrestrial ecoregions shown in $\mathbf{b}$. Data sources are presented in Supplementary Table 1.

mirrored by many forms of societal diversity ${ }^{21}$. For example, tropical countries contain $40 \%$ of the world's population yet $85 \%$ of extant languages are spoken within them ${ }^{22}$. The tropics also provide incalculable benefits to humanity. They housed most of the key centres of plant domestication $^{23}$ and have been a vital laboratory for the development of science itself - the disciplines of ecology, biogeography and evolutionary biology are founded on evidence gleaned from tropical ecosystems. Tropical ecosystems also make vital contributions to globally important ecosystem services. Although they cover just $0.1 \%$ of the ocean surface, coral reefs provide fish resources for the 275 million people that live within $30 \mathrm{~km}$ of them ${ }^{24}$ and coastal protection for up to 197 million people ${ }^{25}$. Humid tropical forests cover less than $12 \%$ of the world's ice-free land surface but produce $33 \%$ of global net primary productivity and store $25 \%$ of the carbon in the terrestrial biosphere ${ }^{26}$, and tropical savannahs provide a further $30 \%$ of global net primary productivity and $15 \%$ of carbon storage ${ }^{27}$. Tropical ecosystems also help drive vital atmospheric teleconnections. For instance, $70 \%$ of the rainfall in the 3.2-million- $\mathrm{km}^{2}$ Rio de la Plata catchment is estimated to come from evaporation in Amazonia ${ }^{28}$.

\section{Vulnerability of tropical biodiversity}

For each of the five vertebrate groups that have been comprehensively assessed by the International Union for the Conservation of Nature (IUCN) and for which spatial occurrence data are available ${ }^{29}$, species classified as Vulnerable, Endangered or Critically Endangered are more dependent on the tropics than are those classified as Least Concern (Fig. 2b). In addition, 85\% of species extinctions from these vertebrate groups have been of species that use the tropics ${ }^{29}$. Consequently, although extinctions of other groups are less well understood, we can assume that most of an estimated 130,000 modern invertebrate extinctions ${ }^{30}$ will also have been of tropical species. Thus, not only are the tropics 
a

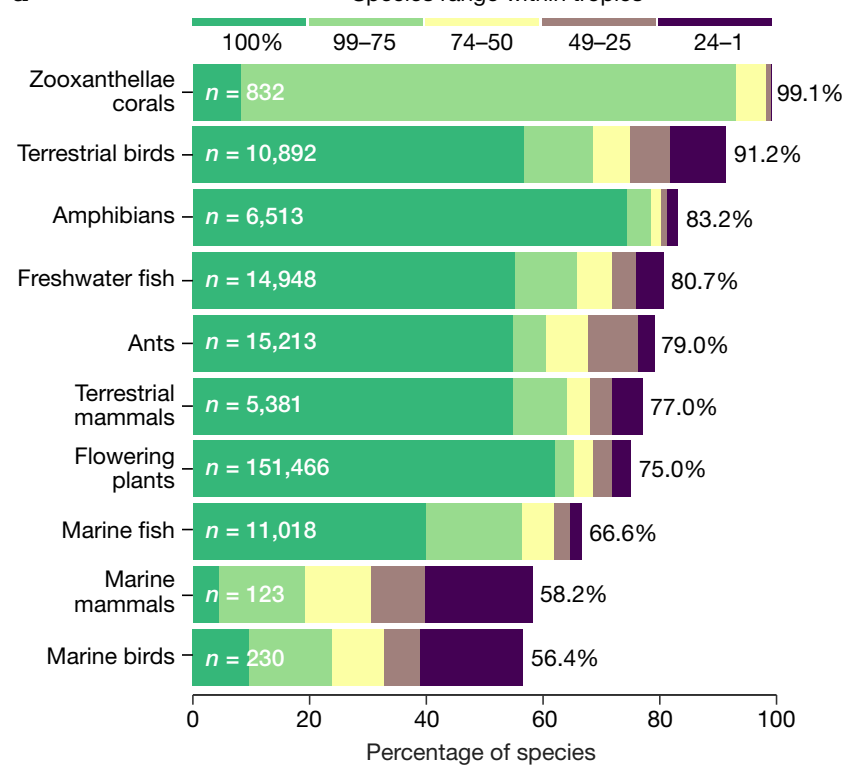

b

$\begin{array}{r}\text { Terrestrial } \\ \text { mammals }\end{array}-n=3,456$
Terrestrial birds $-n=2,529$
Amphibians $-n=2,777$
Marine $-n=50$
Marine birds $-n=118$
$0 \quad 10 \quad 15$

Fig. 2 Tropical hyperdiversity. a, The proportion of species found within tropical latitudes for ten taxonomic groups. Bars are colour-coded to show the percentage of species ranges within the tropics. $n$ gives the total number of species analysed in each group. Only birds, amphibians and mammals have been comprehensively sampled. Numbers at the end of the bars give the precise percentage of species whose ranges overlap tropical latitudes, as shown in the bars. $\mathbf{b}$, The difference in the proportion of threatened (IUCN Critically Endangered, Endangered and Vulnerable categories) and non-threatened (IUCN Least Concern category) species found exclusively within tropical latitudes for the five comprehensively sampled groups. For example, $66 \%$ of threatened and $44 \%$ of nonthreatened terrestrial mammals are confined to the tropics.

The bars show the difference between these figures, which is $22 \%$ in the case of terrestrial mammals. Data are from Birdlife International ${ }^{165}$ (for birds), the IUCN ${ }^{29}$ (for amphibians and mammals), the Ocean Biogeographic Information System (for marine fish), C. Veron (personal communication) (for shallow-water zooxanthellate corals), the Global Biodiversity Information Facility (for flowering plants) and a previous publication $^{166}$ (for freshwater fish). Data sources are presented in Supplementary Table 1.

vastly more diverse than temperate regions, but this diversity is also at far greater risk from human actions ${ }^{31}$. Moreover, given that the tropics have the highest proportion of species classified by the IUCN as Data Deficient and the lowest level of biodiversity-threat assessment ${ }^{16}$, information shortfalls mean we are probably underestimating the vulnerability of the tropical biome. We assessed this vulnerability in more depth by examining the effect of local and global stressors, the interactions between them and the resulting changes to tropical ecosystems.

\section{Local stressors}

The tropics are subject to some of the highest global rates of landuse change and degradation. Since 1990, while the spatial coverage of temperate forests has increased, tropical deforestation rates have exceeded five million hectares per year ${ }^{32}$. Additional effects stem from the expansion of large infrastructure projects, such as dams, and the growing demand for agricultural commodities, biofuels, timber, wood for fuel, and other natural resources ${ }^{33}$. All of these result in severe biotic responses. Even with mitigation, dams present a near-impassable barrier for river fish ${ }^{34}$, and deforestation replaces a species-rich pool of forest specialists with a smaller pool of common open-area species ${ }^{35}$. The influence of land-use change also extends far into remaining natural areas through isolation and edge effects ${ }^{36}$, additional anthropogenic disturbances $\mathrm{s}^{37}$ and altered climatic conditions ${ }^{38}$. Edge effects suppress the abundance of threatened vertebrates up to $200-400 \mathrm{~m}$ into tropical forests $^{36}$; this has left almost no core forest refugia in the Brazilian Atlantic forest, of which over $80 \%$ is within $500 \mathrm{~m}$ of an edge ${ }^{39}$. Even low levels of landscape modification have marked effects on range-restricted species $^{37}$, and time lags mean that some of the most deleterious effects are only observed decades after landscape modification ${ }^{40}$.

Pollution presents a diverse set of threats to tropical ecosystems. Inputs of sediment and nutrients from land-use change are wellestablished drivers of biodiversity loss across freshwater ${ }^{41}$ and coastal systems, including coral reefs ${ }^{42}$. Pesticide use is increasing across the tropics, reflecting rapid intensification of farming practices ${ }^{43}$ and high pressures from pests on tropical crops ${ }^{44}$. Tropical Asian rivers are a major source of the 1.2-2.4 million tonnes of plastic that enters the world's oceans each year ${ }^{45}$, with micro-plastics entering coral diets ${ }^{46}$ and larger debris increasing rates of coral disease ${ }^{47}$. These examples of chronic pollution are exacerbated by extreme events such as the collapse of the Fundão Dam, which released about 50 million cubic metres of waste into a $600-\mathrm{km}$ stretch of river in south-east Brazil and caused a $7,000-\mathrm{km}^{2}$ toxic plume in the Atlantic Ocean ${ }^{48}$.

Overexploitation is also pervasive across the tropics. Fishing has reduced fish biomass by over $75 \%$ across a third of coral reefs ${ }^{49}$ and is shrinking the mean body size of exploited freshwater taxa $\mathrm{a}^{50}$. Hunting has contributed to the loss of charismatic megafauna, extirpating African elephants, rhinoceroses and large predators from most of their original ranges ${ }^{51,52}$. Tropical forests are affected by extensive over-harvesting of wildlife ${ }^{31}$, with estimates of the annual harvests of highly trafficked animals such as pangolins reaching into the millions of individuals ${ }^{53}$. Moreover, the growth in non-food uses of wildlife means that even small-bodied songbirds are at risk of global extinction ${ }^{54}$. Overexploitation also extends beyond fauna and is driving economically valuable tropical tree species to extinction ${ }^{55}$.

Invasive species have been the second most important driver of vertebrate extinctions since $\mathrm{AD} 1500^{56}$. Within terrestrial ecosystems, invasive species have exerted the strongest influence on islands and coastal mainlands ${ }^{57}$, causing thousands of species extinctions and altering trophic structures ${ }^{58}$. On continents, invasive species currently have a greater effect on biodiversity in economically developed and extra-tropical regions, but tropical ecosystems are predicted to become increasingly vulnerable to invasion as the 21 st century continues ${ }^{50}$. Despite a deficit of research in the tropics ${ }^{60}$, two prominent examples highlight the scope and magnitude of species invasions into terrestrial tropical ecosystems: there was an $84 \%$ increase in detections of alien species between 2003 and 2010 in Singapore ${ }^{61}$, and invasive African grasses could threaten up to $380,000 \mathrm{~km}^{2}$ of Australia's savannahs by promoting landscape flammability ${ }^{62}$. In aquatic ecosystems, invasive predatory fish - such as the Indo-Pacific lionfish in Caribbean coral reefs ${ }^{63}$ or the Nile perch in African lakes ${ }^{64}$ - have contributed to the loss of native species. Marine invasions are also facilitated by the mass transport of species in the ballast water of ships, which results in widespread biotic homogenization ${ }^{65}$.

\section{Global climate change}

Many of these local stressors are promoted by globalized drivers, but climate change is truly global. Increases in atmospheric $\mathrm{CO}_{2}$ concentrations to levels higher than 400 p.p.m. have important implications for tropical terrestrial and aquatic ecosystems. Ocean acidification from dissolved $\mathrm{CO}_{2}$ is changing ocean chemistry to the extent that declining coral calcification has already been detected ${ }^{66}$. Conditions for reef accretion and growth may be mostly absent throughout the tropics by the year 2100 under 'business-as-usual' emission scenarios ${ }^{67}$. Within 


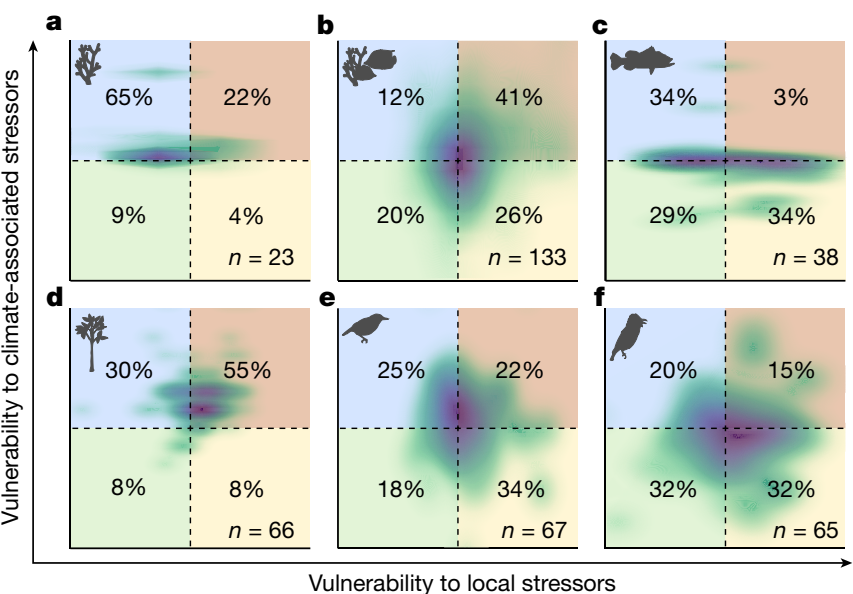

Fig. $3 \mid$ Vulnerability of tropical biota to local and climatic stressors., Species co-tolerance to a local and climate-associated stressor ${ }^{85}$. The $x$ axis shows responses to fishing for corals (a), reef fish (b) and freshwater fish (c); changes in landscape configuration for small-stemmed trees (diameter at breast height between 2 and $10 \mathrm{~cm}(\mathbf{d})$ ) and forest birds (e); and fire suppression for savannah birds (f). The $y$ axis represents longitudinal responses to climate-associated events: the 2015-2016 and 1997-1998 coral bleaching events in the Seychelles for corals (a) and reef fish (b), respectively; the 1997-1998 El Niño-induced drought for lower Amazonian freshwater fish (c); Amazonian fires during the 2015-2016 E Niño event for small-stemmed trees (d) and forest birds (e); and shrub encroachment between 1998-2008 in South Africa for savannah birds (f) Species relative density is represented from low (light green) to high (dark blue). The four quadrants represent the location of 'survivor' species tolerant to both stressors (green), species only susceptible to local stressors (yellow), species only vulnerable to climate-associated stressors (blue) and 'double jeopardy' species susceptible to both stressors (red). Numbers show the percentage of species that fall into the quadrant. $n$ gives the total number of species (genera for corals). Data sources are presented in Supplementary Table 1.

savannahs, elevated $\mathrm{CO}_{2}$ levels favour the growth of woody plants over grasses, contributing to woody encroachment and the potential for a switch in biome state ${ }^{68,69} \cdot \mathrm{CO}_{2}$ fertilization may also have contributed to enhanced tree productivity and mortality rates observed in humid tropical forests ${ }^{70}$.

Global warming is not proceeding at the same rate across the planet Although the greatest absolute temperature increases are occurring at higher latitudes, the tropics are already some of the hottest places on the planet and have the lowest inter-annual temperature variability ${ }^{71,72}$. Consequently, they will be the first areas to experience significantly warmer climates than the present day ${ }^{72}$ and will endure climatic conditions without present-day equivalents ${ }^{71}$. In addition, some of the most important climate oscillations - including El Niño and the Indian Ocean Dipole - take place within and exert their greatest influence on, tropical regions. It is unclear whether these oscillations will change in a warming world, but extremes of their phases have the potential to exacerbate or ameliorate the overall warming trend. One outcome of increasing temperatures is the pole-ward shift of species ranges or movement to higher altitudes or deeper depths ${ }^{73}$. For example, corals in southern Japan are extending northwards at about 14 kilometres per year ${ }^{74}$, and temperate macroalgal communities are being replaced with corals and other tropical species along large stretches of Australian coastline ${ }^{75}$. Latitudinal shifts in terrestrial and freshwater tropical species distributions are less certain, because of the many natural and anthropogenic barriers to species movement and the low dispersal capacity of many tropical species ${ }^{76}$. Furthermore, the responses of terrestrial species are defined by changes in rainfall as well as temperature ${ }^{77}$.

If movement is not an option, tropical species must adapt or face extinction. Unfortunately, there is evidence that some species are either approaching their physiological limits or are unable to adapt to the current rate of environmental change ${ }^{78}$. Increasing ocean temperature extremes are driving mass-bleaching events and motality of reef- -forming corals, with the time between bleaching events declining by $76-80 \%$ since the early $1980 \mathrm{~s}^{79}$. Higher temperatures also affect tropical vertebrates - for example, by causing an extreme female bias in the sex ratio of green turtles in the warmer regions of the Great Barrier Reef ${ }^{80}$ and a reduction in the reproductive success of African wild $\operatorname{dog} s^{81}$. Altered rainfall is also critical. Droughts are drying up biologically diverse small streams ${ }^{82}$, and even modest changes in dry-season length increase tropical tree mortality ${ }^{70}$ and modify tropical forest bird community structure ${ }^{83}$.

\section{Interacting stressors and indirect effects}

Stressors affecting tropical species can interact in myriad ways ${ }^{84}$. We demonstrate this by compiling data from six case studies within a cotolerance framework that enables the examination of species responses to two dominant stressors ${ }^{85}$. Only a small subset of species or genera (8-32\%) showed no or positive responses when both stressors were combined (Fig. 3), and up to 55\% fell within the 'double jeopardy' quadrant that indicates a negative response to both stressors. Although our summary does not quantify the magnitude of effects, it clearly demonstrates that stressors can act together to reduce the abundance or occupancy of tropical species. Moreover, most tropical ecosystems are affected by more than two stressors at any given location and time ${ }^{84}$, and co-tolerance analyses of this type are likely to underestimate the reality of human impacts.

Many changes to tropical ecosystems result from the indirect consequences of single or multiple stressors. On coral reefs, nutrient inputs from the land may increase susceptibility to coral bleaching, disease and outbreaks of pests ${ }^{86}$, and pole-ward reef expansion is supported by feedbacks from range-shifts in tropical herbivorous fish ${ }^{75}$. Overexploitation can result in surprising changes in tropical ecosystem properties through trophic cascades. For instance, the extirpation of a single detritivore fish species in the Orinoco basin reduced downstream organic-carbon transport, which in turn increased net primary productivity and respiration ${ }^{87}$. On reefs, the overfishing of keystone predators has repercussions for benthic structure ${ }^{88}$, and the removal of herbivores can limit coral recovery from mass-mortality events ${ }^{89}$. In mesic savannahs, changes to herbivore numbers alter ecosystem functions and structure through their interactions with wildfire regimes ${ }^{90}$. Invasive species are also frequently linked to other stressors: the introduction of the Nile perch had a major role in the decline of endemic fish species in Lake Victoria, but these declines were also catalysed by a combination of other drivers including soil erosion, eutrophication and overfishing ${ }^{64}$.

\section{Ecosystems in transition}

Interactions between multiple anthropogenic stressors are causing pervasive changes in the tropics, such that alternative states are emerging across all major tropical ecosystems (Fig. 4). Perhaps counterintuitively, trees are encroaching on savannahs and grasses are invading disturbed tropical forests - however, in both cases the changes are from species-rich to species-poor systems ${ }^{68,91}$.

These marked ecosystem transitions are accompanied by widespread modification of species composition. For example, the relative abundance of coral species has been altered on reefs that maintain coral dominance $^{92}$; the extirpation of native fish has followed species introductions in lakes ${ }^{64}$; liana biomass has increased in otherwise undisturbed Neotropical forests ${ }^{93}$; and patterns of plant regeneration in humid forests have been altered by the overharvesting of seed-dispersing vertebrates ${ }^{31,94}$. Altered species composition is a cause for concern because it could signal the onset of more severe modification, especially if dominant species are vulnerable to other stressors or if there are cascading implications for ecosystem functioning. The collapse of Jamaican coral reefs provides one of the starkest examples. First, chronic overfishing depleted herbivorous fish populations, which left the system over-reliant on sea urchins for grazing algae. Then, in 1980, Hurricane Allen affected the system, creating a substantial amount of dead substrate. Although corals began to recover after the hurricane, the subsequent mass mortality of sea urchins owing to disease - combined with the fact that herbivorous fish were already at low levels of abundance - led to a phase shift from coral to macroalgal dominance ${ }^{95,96}$ 
a

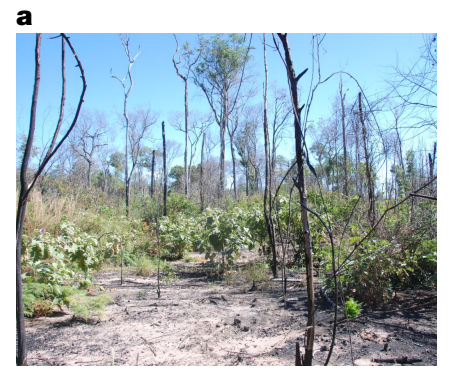

b

c

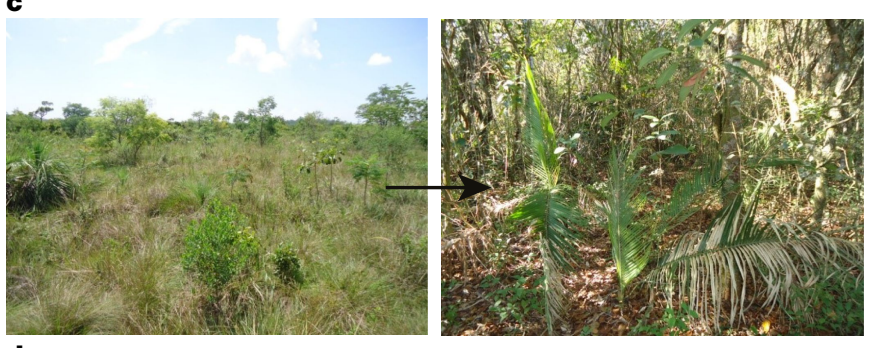

d

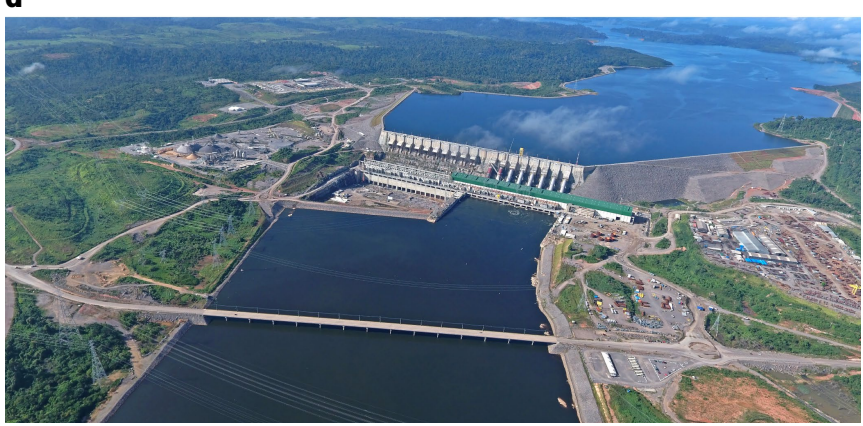

Fig. 4 Tropical ecosystems in transition. a, Recurrent wildfires in historically fire-free humid tropical forests ${ }^{167}$ can lead to the dominance of grassy vegetation that impedes succession towards closed-canopy forests 91,168 . These wildfires result from the combination of local actions (for example, agricultural practices and logging) and climate change that has increased the prevalence of weather that promotes wildfires ${ }^{169} . b$, Chronic local pressures and acute climatic stressors can lead to coral cover being replaced by macroalgae, sponges or sediment-laden turf algae $^{89,95}$. During the 1998 global coral-bleaching event, $>90 \%$ of live coral died in the inner Seychelles and nearly half of the reefs transitioned to fleshy macroalgal regimes ${ }^{89}$. c, Woody encroachment is occurring in many savannahs ${ }^{69}$, causing biodiversity loss and altered system functioning ${ }^{68}$. Causes are mixed: regime shifts to forest-associated ecosystems have been attributed to fire suppression policies (for example, Brazilian cerrado (left) to forest (right) ${ }^{170}$ ), or changes in herbivory and increasing atmospheric $\mathrm{CO}_{2}{ }^{69}$. $\mathbf{d}$, The boom in hydropower dam construction is affecting large tropical river basins ${ }^{134}$. The transformation from lotic to lentic conditions reduces access to riparian and floodplain habitats that are nursery areas and feeding grounds for many of the species occupying higher trophic levels, leading to major shifts in species composition and ecosystem function ${ }^{82}$. Images from J.B. (a), N.A.J.G. (b), G. Durigan (c) and C.G.L. (d), used with permission.

\section{Socio-economic context and response capacity}

The interacting proximate stressors causing tropical environmental change are underpinned by broader changes in socio-economic and political factors. We examined the trajectories of four types of underlying distal drivers, including demography and the economy (Fig. 5a, b), socio-political factors (Fig. 5c, d), markets (Fig. 5e, f) and technology ${ }^{97}$ (Fig. $5 \mathrm{~g}, \mathrm{~h}$ ) to explore how tropical countries are changing relative to the rest of the world and to evaluate the relative influence of local and global drivers. We also examined how the capacity of tropical countries to reduce or cope with proximate stressors compares to non-tropical countries based on underlying governance systems (Fig. 5i, j) and research capacity (Fig. 5k, 1).

The immense biodiversity of the tropics exists in the context of rapid demographic and economic growth (Fig. 5a, b). The human population is growing at a faster rate in the tropics than elsewhere (Fig. 5a), and by 2050 half of the world's population will live in the tropics ${ }^{2}$. These demographic changes are accompanied by a steady growth in gross domestic product (GDP) that is linked in part to the rapid expansion of agricultural and extractive industries. However, in the tropics, per capita GDP - which is an important measure of human well-being - remains far lower than the non-tropical average (Fig. 5b) and the rates of change suggest that there has been little closing of the global inequality gap. Although the relationship between development and natural resource conservation does not have to be negative ${ }^{98,99}$, measures that reflect higher social performance are almost always associated with higher resource use ${ }^{99}$. A larger and more affluent tropical population will increase demands for timber, water, food, energy and land, all of which are strongly linked with environmental degradation.

These internal changes will be exacerbated by economic growth in non-tropical countries and the continued displacement of environmental effects to less-developed areas ${ }^{100}$. Indeed, despite high levels of tropical cultural diversity ${ }^{21,22}$, external socio-political influences (Fig. 5c, d) suggest that tropical countries have become increasingly susceptible to globalization. For example, the proportion of imported food crops (Fig. 5c) and foreign land acquisitions are far higher in the tropics than elsewhere (Fig. 5d) and are associated with extensive road building ${ }^{101}$ and agricultural investment ${ }^{102}$. These trends towards increasing tropical globalization are reinforced by changes in market integration (Fig. 5e, f) and technological development (Fig. 5g, h). For example, agricultural exports (Fig. 5f) are steadily increasing, albeit from a far lower baseline than the rest of the world. Moreover, given comparatively low levels of adoption of technological developments, such as industrial fishing techniques (Fig. 5g) or fertilizers (Fig. 5h), there is an enormous risk that the rate of natural resource extraction in many tropical countries will increase further, to supply both domestic and export markets ${ }^{103,104}$. Taken together, these examples highlight the crucial role that external markets will have in determining the fate of tropical ecosystems.

Effective environmental governance (Fig. 5i, j) is a necessary condition for improved sustainability outcomes ${ }^{105}$, particularly when domestic (Fig. 5a, b) and global (Fig. 5c-f) distal drivers are expected to exert increasing and unsustainable pressure on tropical ecosystems ${ }^{2,102}$. However, national-level assessments of governance effectiveness place the tropics far below extra-tropical countries, with no sign of improvement (Fig. 5i). External support for environmental governance may help where local governance is weak. Yet, despite the biological importance of the tropics, levels of environmental aid from the Organisation for Economic Cooperation and Development (OECD) are only marginally greater in the tropics than elsewhere (Fig. 5j), and these investments are dwarfed by the value of domestic resource extraction (for example, agricultural exports; Fig. 5f), the value of which is two orders of magnitude greater than overseas environmental aid. Furthermore, OECD environmental aid has been declining in recent years and seems unlikely to increase in the short term ${ }^{106}$.

Low governance capacity in the tropics is further exacerbated by insufficient research and development investment (Fig. 5k) and low levels of scientific output (Fig. 51). Research investment is critical for driving innovation and the development of evidence-based solutions to environmental degradation ${ }^{107}$. Despite some notable centres of excellence, the vast majority of biodiversity-related data and research is concentrated in wealthy, non-tropical countries ${ }^{107}$, and manuscripts submitted by authors from low-income countries are less than half as likely to be published as those from high-income countries ${ }^{108}$. These trends highlight an alarming disconnect between the global scientific process and the people that are most capable of engaging with decision makers in tropical countries, who have the best understanding of local context and, arguably, have the strongest incentive to achieve positive outcomes for tropical conservation through their research.

\section{Diverse solutions for diverse systems}

Tropical ecosystems - and therefore at least $78 \%$ of global biodiversity (Fig. 2a) - are at a critical juncture. Multiple interacting local and global stressors (Fig. 3) that are driving species extinctions and potentially irreversible ecosystem transitions ${ }^{92,109}$ (Fig. 4) are set within 

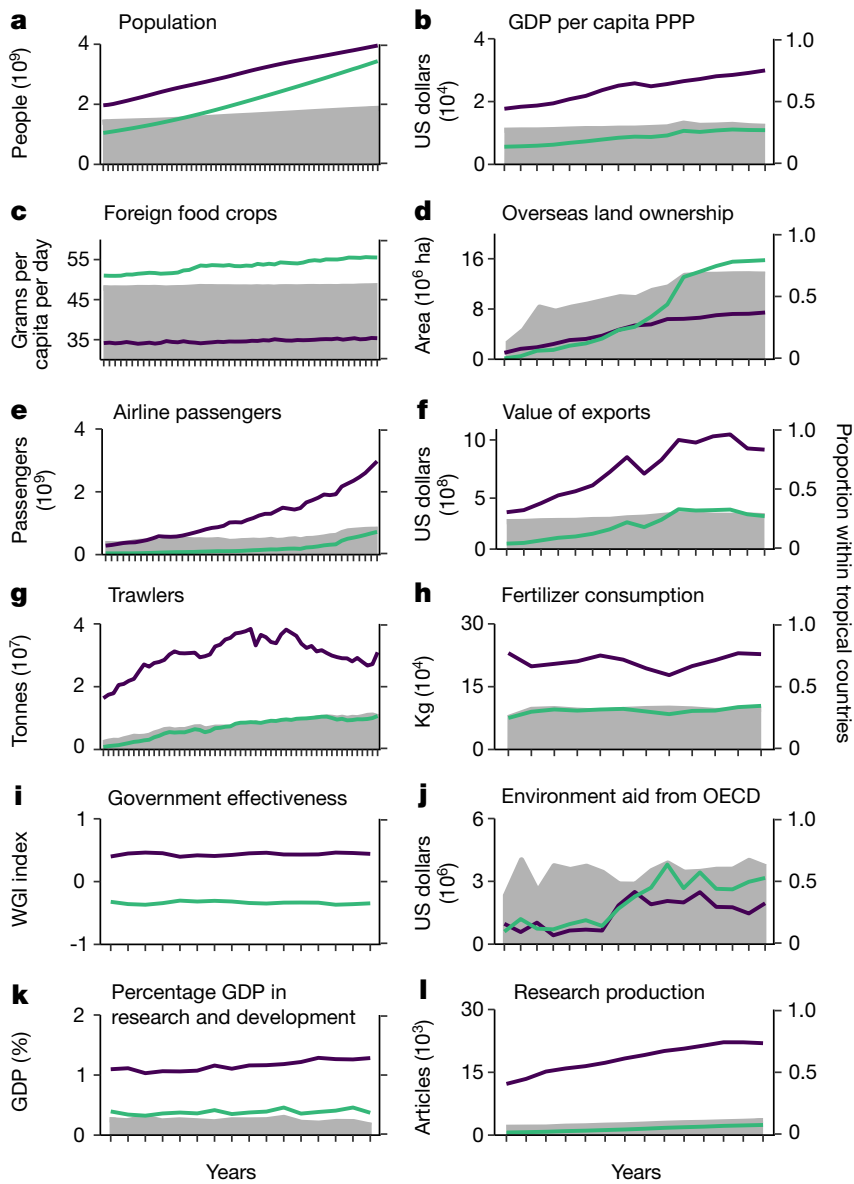

Fig. 5 Socio-economic drivers of biodiversity loss and societal response capacities. Green lines represent countries with $>50 \%$ of their area within tropical latitudes; purple lines represent all other countries; grey-shaded areas represent the proportion of the global total within tropical countries. a, Population (1960-2016). b, GDP per capita (2011 US dollars, based on purchasing power parity; 2000-2016). c, Foreign food crops (1961-2009). d, Cumulative overseas land ownership (2001-2017). e, Domestic and international airline passengers (1970-2016). f, Agricultural and forestry commodities export value (2001-2016). g, Bottom and pelagic trawler catch tonnages (1960-2014). h, Total fertilizer (nitrogen, potash and phosphate) consumption relative to crop area (2002-2013). i, Government effectiveness index (2000-2016). WGI, World Governance Indicators. j, Environmental aid (2000-2016). k, Public and private sector research and development expenditure as a percentage of GDP (2000-2015). l, Scientific and technical journal articles per million people in the fields of physics, biology, chemistry, mathematics, clinical medicine, biomedical research, engineering and technology, and Earth and space sciences (2003-2016). Data sources are presented in Supplementary Table 1.

a changing socio-economic context (Fig. 5). This changing context is characterized by growing and more affluent populations, an increasingly globalized world, and weak governance and research capacity all of which threaten to increase environmental degradation, conflict and inequality $^{102}$. Countering these threats requires major improvements in local and global governance capacity and a step-change in how environmental objectives are integrated into broader development goals ${ }^{110}$. We review the opportunities and limitations presented by three wellestablished and non-mutually exclusive approaches to conservation, before highlighting priorities for research.

\section{Conservation approaches}

A fundamental element of tropical conservation relies on protected areas to limit demographic pressures and the effect of local stressors. These are supported by a wealth of scientific evidence outlining the pervasive effect of local stressors across tropical ecosystems ${ }^{37,49}$ (Fig. 3) combined with an eco-centric philosophy that emphasizes the intrinsic rights of nature ${ }^{111}$. Despite a substantial expansion of protected area coverage in the marine and forested tropics ${ }^{112}$, the current network remains poorly designed, has very limited coverage of tropical freshwaters and grasslands, and is inadequately resourced ${ }^{113}$. Moreover, a strategy focused solely on protected areas may not foster environmental conservation outside of reserves ${ }^{114}$ and fails to engage with the distal drivers of biodiversity loss (Fig. 5) that can undermine the effectiveness of protected areas themselves ${ }^{115}$.

A second set of approaches for tropical conservation is based on the notion that people need to perceive the benefits of nature to justify conservation. These approaches emphasize the need to pursue conservation objectives in human-dominated landscapes, the provision of ecosystem services and the involvement of private-sector actors. In the tropics, they are epitomized by the growth in market-based conservation payment mechanisms, such as REDD+ ${ }^{116}$, investments in the 'blue economy' ${ }^{117}$ and a step-change in the number of companies making sustainability commitments $^{118}$. These approaches have strengthened the conservation toolkit, especially where strict regulatory approaches have failed. Encouraging examples range from the positive effects of commodity certification (for example, palm oil ${ }^{119}$ ) to payment for ecosystem service schemes (for example, watershed protection ${ }^{120}$ ). However, such approaches also attract considerable criticism, with implementation often lagging behind commitments ${ }^{118}$, persistent concerns around the social legitimacy of compensation schemes ${ }^{121}$ and the misalignment of market-based mechanisms with local needs and perceptions of environmental values ${ }^{122}$.

A third and more diverse set of approaches is based on the recognition of the interdependencies between people and nature, the coevolution of ecological and socio-economic systems at local, regional and global scales ${ }^{123}$, and perspectives about the co-existence of people and nature. This set of 'systems-based' approaches includes: (1) an appreciation of the importance of bottom-up, community-based conservation approaches in human-dominated land- and seascapes (for example, small-scale fisheries ${ }^{124}$ and community-managed forests ${ }^{125}$ ); (2) recognition of the role of indigenous people as environmental stewards and shifts towards an appreciation of more collective relationships with nature (for example, the Ecuadorian constitution ${ }^{126}$ ); (3) landscape- and ecosystem-wide approaches that attempt to bridge the role of actors working at different scales and in different sectors (for example, jurisdictional approaches to curb deforestation ${ }^{127}$ ); and (4) a more explicit accounting of multi-scale feedbacks, including the role of distant market actors and distal drivers ${ }^{123}$. These broad, multi-layered 'people and nature' approaches hold considerable appeal but the inherent complexity of local contexts can make them challenging to conceptualize, implement and measure in joined-up and consistent ways ${ }^{128}$.

\section{Acting together and acting now}

The three approaches to the conservation and governance of tropical ecosystems outlined above are often associated with alternative researcher and practitioner worldviews ${ }^{129,130}$. However, the ecological diversity (Fig. 2a), vulnerability (Figs. 2b, 3) and socio-economic complexity (Fig. 5) of the tropics highlights the importance of pluralism ${ }^{131}$ and the need to adopt a variety of what are often complementary and synergistic approaches ${ }^{130}$. For all their deficiencies, protected areas are indispensable to limit the effect of local stressors, and it will be impossible to avoid further biodiversity loss unless they are strengthened and expanded ${ }^{132}$. However, conservation strategies must also address the underlying drivers of environmental change (Fig. 5) and avoid exacerbating deeply rooted inequalities ${ }^{114}$. Practice is always messier than theory, and the adoption of more sustainable management systems is usually only possible with the support of a range of actors, as can be seen in the recent successes of some hybrid governance approaches, with government, the private sector and civil society organizations all having vital roles ${ }^{133}$.

Another clear message is that conservation efforts need to operate at local, regional and global scales to be effective. Many distal drivers are disconnected in both space and time from the sites they affect, and the engagement of external actors - including in distant markets and governance processes - is often essential to ensure that local efforts are effective. These include more strategic integration of environmental policy with development goals ${ }^{134}$, the need for multi- 
national environmental governance approaches, especially for aquatic systems $^{82}$, and recognition of the importance of tackling demand for unsustainable products from downstream buyers and investors ${ }^{118}$. The capstone of such efforts lies in the urgent need to deliver on the Paris Agreement, without which climate change will undercut or even negate hard-won local conservation successes, whether in coral reefs ${ }^{92}$ or tropical forests ${ }^{109}$.

Finally, we need to act now to address the pressing environmental challenges facing the tropics. This means being adaptive, learning by doing and embracing innovation. The past decades have seen a boom in proposals, innovations and insights about the governance and management of tropical ecosystems, ranging from more technocentric proposals to facilitate the evolution of climate-tolerant corals ${ }^{135}$; ecological engineering to recover lost trophic interactions by species re-introductions, ecological replacements and rewilding ${ }^{136}$; to radical new legal frameworks such as France's 'Loi de vigilance' (2017-399; https:/www.legifrance.gouv.fr/eli/loi/2017/3/27/2017-399/jo/texte) that places an unprecedented due diligence obligation on major companies to assess social and environmental risks in their supply chains that extend beyond French borders. Though these innovations serve different purposes and are varyingly scalable, they illustrate the potential of solutions-based science and conservation. Of course, acting now does not mean ignoring the existing evidence base or making uninformed decisions. Rather, it is vital that researchers and decision makers are vigilant to opportunities and risks and are willing to learn lessons.

\section{Keeping pace with the Anthropocene}

All approaches to governing tropical ecosystems will be more effective if they have local support and are based on strong scientific evidence that ensures, for example, that protected areas are located where they are most needed, ecosystem services are accurately quantified, extractive activities such as fishing and logging are managed sustainably, and underlying drivers of environmental degradation are identified and understood. Although these challenges are common to all conservation and sustainability science, they are magnified in the tropics owing to the unique diversity and high vulnerability of tropical ecosystems and the low research capacity of most tropical countries. Here we examine four areas in which research effort can be more closely aligned with some of the priorities highlighted by this review.

\section{Addressing key knowledge shortfalls}

Our understanding of tropical biodiversity is limited by substantial shortfalls in knowledge regarding taxonomy and species distributions ${ }^{137}$. Overcoming these shortfalls will require targeting resources towards the data-scarce regions that cover so much of the tropics $^{18}$. At the ecosystem level, there is a need for increased study of structurally and functionally distinct systems, particularly tropical grassy biomes ${ }^{68}$, dry forests ${ }^{138}$ and low-order stream systems ${ }^{139}$. Progress in these areas is likely to be aided by advances in DNA sequencing and informatics, which have the potential to invigorate taxonomic discovery, and by reaching across cultural divides to incorporate national, regional and local knowledge that often remains ignored because it is not available in English ${ }^{140}$, included in standard databases ${ }^{141}$ or recognized by conventional science ${ }^{142}$.

\section{Understanding vulnerability}

Our growing knowledge of the role of individual stressors, such as landscape configuration or overexploitation, needs to be complemented by research on the effect of multiple stressors ${ }^{84}$, which could help predict and mitigate complex biotic responses when climate and local stressors act in concert (Fig. 3). Other phenomena that are important but harder to study include the role of time lags or extinction debts ${ }^{40}$, trophic cascades $^{31}$ and trajectories of ecosystem degradation and recovery in the face of unprecedented environmental change ${ }^{143}$. Revealing these more-complex forms of vulnerability will often demand longer-term and larger multi-scale sampling and monitoring programs. New approaches are also needed to overcome one of the more intractable challenges of tropical ecology: the fact that we often know least about the rarest and most vulnerable species or taxonomic groups.

\section{Understanding distal drivers}

Conservation does not occur in a vacuum, and local interventions are likely to be much more effective if they are guided by a closer understanding of underlying distal drivers of biodiversity loss and environmental change, including identifying the actors behind such drivers, which will help to determine potential trigger points and identify more effective policy responses ${ }^{97}$. Unpicking the role of distal drivers is essential to understand how distant interactions between social and environmental systems shape local environmental outcomes ${ }^{144}$. Careful study has revealed many surprising interactions, such as links between the intensification of commercial fishing and increased bushmeat exploitation in west Africa ${ }^{145}$, the role of warfare in driving African mammal declines ${ }^{146}$ or the role of currency exchange rates in driving deforestation ${ }^{147}$. Achieving this deeper understanding requires greater integration of the natural and social sciences, with interdisciplinarity included as a core element of tropical conservation research ${ }^{148}$.

\section{From research to impact}

Achieving positive effects from conservation research relies on building a stronger interface between science and society that challenges the oversimplified assumption of a linear flow from knowledge to action ${ }^{149}$. Engendering positive changes will require closer participation of practitioners in the research process and investments in outreach activities and professional capacity building ${ }^{149}$. These will be supported by studying the knowledge exchange process itself, including the critical part that is played by knowledge brokers and boundary organizations ${ }^{150-152}$. Part of this process will require a focus on success stories or 'bright spots', which will enable the social, institutional and environmental conditions that create positive outcomes to be identified and replicated ${ }^{151}$. The positive social and ecological outcomes from innovative restoration and rewilding programmes in Costa Rica and Mozambique demonstrate the potential for positive action ${ }^{153}$.

Local managers and scientists have a vital role in designing and implementing research that can inform regionally appropriate conservation actions $^{154}$. At present, our knowledge of hyperdiverse ecosystems is over-reliant on inferences gleaned from distant research stations or inappropriate theoretical constructs developed for temperate contexts ${ }^{18,155}$. Research is also more likely to have an effect if the spatial scale of studies is closely matched to the administrative scale at which resource decisions are taken ${ }^{156}$. Sustaining research programmes and learning networks in study landscapes can help build vital relationships between researchers, local knowledge holders and decision makers ${ }^{154}$.

Achieving these changes requires building on trends in the technological, disciplinary and cultural dimensions of research practice. In the technological domain, opportunities for data collection have been revolutionized by developments in remote sensing and drones ${ }^{157}$, the plummeting costs of DNA technologies ${ }^{158}$ and the step-changes in bioinformatics that have enabled 'big data' to be stored and retrieved in open-access platforms ${ }^{159}$. In the disciplinary domain, the past decade has seen a marked upward trend in interdisciplinary and transdisciplinary research and a greater - albeit still insufficient - integration of natural and social sciences. This has resulted in an increasing openness of researchers towards methodological pluralism and mixed-method approaches ${ }^{149}$ and a growing recognition of the contribution that can be made by local people and citizen- and para-scientists in biodiversity research ${ }^{160}$. Changes in research culture include the greater internationalization of ecological science and closer approximation with society ${ }^{149}$, both of which can help foster more fertile ground for knowledge exchange and capacity building. Notable advances include the development of multi-disciplinary and multinational learning networks ${ }^{161}$, exponential growth in author teams ${ }^{162}$ and major syntheses such as the Intergovernmental Platform for Biodiversity and Ecosystem Services.

Recent years have seen an awakening of environmental consciousness and calls for decisive action that are manifest, for example, in the Paris Agreement, the Sustainable Development Goals and voluntary Zero Deforestation Commitments. Scientists from tropical and nontropical regions can inform these endeavours by developing a reliable knowledge base and innovative management interventions. Overcoming the remaining research challenges is far from trivial and will require a massive investment of resources to develop scientific infrastructure 
and capacity within tropical nations, as well as profound changes to ways of working and the relationship between the research process and society at large. But a failure to act decisively and to act now will greatly increase the risk of unprecedented and irrevocable biodiversity loss in the hyperdiverse tropics.

1. United Nations General Assembly. Transforming our world: the 2030 Agenda fo Sustainable Development (United Nations, New York, 2015).

2. Edelman, A. et al. State of the Tropics: 2014 Report (James Cook Univ., Cairns, 2014)

3. Moreau, C. S. \& Bell, C. D. Testing the museum versus cradle tropical biological diversity hypothesis: phylogeny, diversification, and ancestral biogeographic range evolution of the ants. Evolution 67, 2240-2257 (2013)

4. Jablonski, D. et al. Out of the tropics: evolutionary dynamics of the latitudinal diversity gradient. Science 314, 102-106 (2006).

5. DeGraaf, R. M. \& Rappole, J. H. Neotropical Migratory Birds: Natural History, Distribution, and Population Change (Cornell Univ. Press, Ithaca, 1995).

6. Hahn, S., Bauer, S. \& Liechti, F. The natural link between Europe and Africa-2.1 billion birds on migration. Oikos 118, 624-626 (2009).

7. Tittensor, D. P. et al. Global patterns and predictors of marine biodiversity across taxa. Nature 466, 1098-1101 (2010).

8. Chown, S. L., Gaston, K. J. \& Williams, P. H. Global patterns in species richnes of pelagic seabirds: the Procellariiformes. Ecography 21, 342-350 (1998).

9. Mora, C., Tittensor, D. P., Adl, S., Simpson, A. G. B. \& Worm, B. How many species are there on Earth and in the ocean? PLoS Biol. 9, e1001127 (2011)

10. Tancoigne, E. \& Dubois, A. Taxonomy: no decline, but inertia. Cladistics 29. 567-570 (2013)

11. Jenkins, C. N., Pimm, S. L. \& Joppa, L. N. Global patterns of terrestrial vertebrate diversity and conservation. Proc. Natl Acad. Sci. USA 110, E2602-E2610 (2013).

12. Guénard, B., Weiser, M. D. \& Dunn, R. R. Global models of ant diversity sugges regions where new discoveries are most likely are under disproportionate deforestation threat. Proc. Natl Acad. Sci. USA 109, 7368-7373 (2012).

13. Burgin, C. J., Colella, J. P., Kahn, P. L. \& Upham, N. S. How many species of mammals are there? J. Mamm. 99, 1-14 (2018).

14. Fisher, R. et al. Species richness on coral reefs and the pursuit of convergent global estimates. Curr. Biol. 25, 500-505 (2015)

15. Agnarsson, I., Coddington, J. A. \& Kuntner, M. in Spider Research in the 21st Century: Trends and Perspectives (ed. Penney, D.) 58-111 (Siri Scientific Rochdale, 2013)

16. Collen, B., Ram, M., Zamin, T. \& McRae, L. The tropical biodiversity data gap: addressing disparity in global monitoring. Trop. Conserv. Sci. 1, 75-88 (2008).

17. Fisher, R. et al. Global mismatch between research effort and conservation needs of tropical coral reefs. Conserv. Lett. 4, 64-72 (2011).

18. Gardner, T. A. et al. Prospects for tropical forest biodiversity in a humanmodified world. Ecol. Lett. 12, 561-582 (2009).

19. Barlow, J., Overal, W. L., Araujo, I. S., Gardner, T. A. \& Peres, C. A. The value of primary, secondary and plantation forests for fruit-feeding butterflies in the Brazilian Amazon. J. Appl. Ecol. 44, 1001-1012 (2007).

20. Baldwin, C. C., Tornabene, L. \& Robertson, D. R. Below the mesophotic. Sci. Rep. 8, 4920 (2018).

21. Collard, I. F. \& Foley, R. A. Latitudinal patterns and environmental determinants of recent human cultural diversity: do humans follow biogeographical rules? Evol. Ecol. Res. 4, 371-383 (2002).

22. Simons, G. F. \& Fennig, C. D. Ethnologue: Languages of the World 20th edn (SIL International, Dallas, 2018)

23. Purugganan, M. D. \& Fuller, D. Q. The nature of selection during plant domestication. Nature 457, 843-848 (2009).

24. Burke, L., Reytar, K., Spalding, M. \& Perry, A. Reefs at Risk Revisited (WRI, Washington, D.C., 2011).

25. Ferrario, F. et al. The effectiveness of coral reefs for coastal hazard risk reduction and adaptation. Nat. Commun. 5, 3794 (2014).

26. Bonan, G. B. Forests and climate change: forcings, feedbacks, and the climate benefits of forests. Science 320, 1444-1449 (2008).

27. Grace, J., San José, J., Meir, P., Miranda, H. S. \& Montes, R. A. Productivity and carbon fluxes of tropical savannas. J. Biogeogr. 33, 387-400 (2006).

28. van der Ent, R. J., Savenije, H. H. G. G., Schaefli, B. \& Steele-Dunne, S. C. Origin and fate of atmospheric moisture over continents. Wat. Resour. Res. 46 W09525 (2010)

29. IUCN. IUCN Spatial Data (2018) http://www.iucnredlist.org/technical-documents/spatial-data

30. Régnier, C. et al. Mass extinction in poorly known taxa. Proc. Natl Acad. Sci. USA 112, 7761-7766 (2015).

31. Dirzo, R. et al. Defaunation in the Anthropocene. Science 401, 401-406 (2014)

32. Keenan, R. J. et al. Dynamics of global forest area: results from the FAO Globa Forest Resources Assessment 2015. For. Ecol. Manage. 352, 9-20 (2015).

33. Steffen, W., Broadgate, W., Deutsch, L., Gaffney, O. \& Ludwig, C. The trajectory of the Anthropocene: the great acceleration. Anthropocene Rev. 2 81-98 (2015).

34. Pelicice, F. M., Pompeu, P. S. \& Agostinho, A. A. Large reservoirs as ecological barriers to downstream movements of Neotropical migratory fish. Fish Fish. 16, 697-715 (2015).

35. Mendenhall, C. D., Shields-Estrada, A., Krishnaswami, A. J. \& Daily, G. C. Quantifying and sustaining biodiversity in tropical agricultural landscapes.
Proc. Natl Acad. Sci. USA 113, 14544-14551 (2016).

6. Pfeifer, M. et al. Creation of forest edges has a global impact on forest vertebrates. Nature 551, 187-191 (2017).

37. Barlow, J. et al. Anthropogenic disturbance in tropical forests can double biodiversity loss from deforestation. Nature 535, 144-147 (2016).

38. Spracklen, D. V. \& Garcia-Carreras, L. The impact of Amazonian deforestation on Amazon basin rainfall. Geophys. Res. Lett. 42, 9546-9552 (2015)

39. Haddad, N. M. et al. Habitat fragmentation and its lasting impact on Earth's ecosystems. Sci. Adv. 1, e1500052 (2015).

40. Gibson, L. et al. Near-complete extinction of native small mammal fauna 25 years after forest fragmentation. Science 341, 1508-1510 (2013).

41. Dudgeon, D. et al. Freshwater biodiversity: importance, threats, status and conservation challenges. Biol. Rev. Camb. Philos. Soc. 81, 163-182 (2006).

42. Altieri, A. H. et al. Tropical dead zones and mass mortalities on coral reefs. Proc. Natl Acad. Sci. USA 114, 3660-3665 (2017).

43. Lewis, S. E., Silburn, D. M., Kookana, R. S. \& Shaw, M. Pesticide behavior, fate, and effects in the tropics: an overview of the current state of knowledge. J. Agric. Food Chem. 64, 3917-3924 (2016).

44. Bebber, D. P., Holmes, T. \& Gurr, S. J. The global spread of crop pests and pathogens. Glob. Ecol. Biogeogr. 23, 1398-1407 (2014).

45. Lebreton, L. C. M. et al. River plastic emissions to the world's oceans. Nat. Commun. 8, 15611 (2017).

46. Hall, N. M., Berry, K. L. E., Rintoul, L. \& Hoogenboom, M. O. Microplastic ingestion by scleractinian corals. Mar. Biol. 162, 725-732 (2015).

47. Lamb, J. B. et al. Plastic waste associated with disease on coral reefs. Science 359, 460-462 (2018).

48. Garcia, L. C., Ribeiro, D. B., de Oliveira Roque, F., Ochoa-Quintero, J. M. \& Laurance, W. F. Brazil's worst mining disaster: corporations must be compelled to pay the actual environmental costs. Ecol. Appl. 27, 5-9 (2017).

49. MacNeil, M. A. et al. Recovery potential of the world's coral reef fishes. Nature 520, 341-344 (2015)

50. Castello, L. et al. The vulnerability of Amazon freshwater ecosystems. Conserv. Lett. 6, 217-229 (2013).

51. Ripple, W. J. et al. Collapse of the world's largest herbivores. Sci. Adv. 1, e1400103 (2015)

52. Ripple, W. J. et al. Status and ecological effects of the world's largest carnivores. Science 343, 1241484 (2014).

53. Ingram, D. J. et al. Assessing Africa-wide pangolin exploitation by scaling local data. Conserv. Lett. 11, e12389 (2017).

54. Eaton, J. A. et al. Trade-driven extinctions and near-extinctions of avian taxa in Sundaic Indonesia. Forktail 31, 1-12 (2015).

55. Barrett, M. A., Brown, J. L., Morikawa, M. K., Labat, J.-N. \& Yoder, A. D. CITES designation for endangered rosewood in Madagascar. Science 328, 1109-1110 (2010).

56. Bellard, C., Cassey, P. \& Blackburn, T. M. Alien species as a driver of recent extinctions. Biol. Lett. 12, 20150623 (2016)

57. Dawson, W. et al. Global hotspots and correlates of alien species richness across taxonomic groups. Nat. Ecol. Evol. 1, 0186 (2017).

58. Simberloff, D. et al. Impacts of biological invasions: what's what and the way forward. Trends Ecol. Evol. 28, 58-66 (2013).

59. Early, R. et al. Global threats from invasive alien species in the twenty-first century and national response capacities. Nat. Commun. 7, 12485 (2016).

60. Pyšek, P. et al. Geographical and taxonomic biases in invasion ecology. Trends Ecol. Evol. 23, 237-244 (2008).

61. Nghiem, T. P. et al. Economic and environmental impacts of harmful non-indigenous species in southeast Asia. PLoS ONE 8, e71255 (2013).

62. Setterfield, S. A., Rossiter-Rachor, N. A., Hutley, L. B., Douglas, M. M. \& Williams, R. J. Turning up the heat: the impacts of Andropogon gayanus (gamba grass) invasion on fire behaviour in northern Australian savannas. Divers. Distrib. 16, 854-861 (2010).

63. Albins, M. A. \& Hixon, M. A. Worst case scenario: potential long-term effect of invasive predatory lionfish (Pterois volitans) on Atlantic and Caribbean coral-reef communities. Environ. Biol. Fishes 96, 1151-1157 (2013).

64. Hecky, R. E., Mugidde, R., Ramlal, P. S., Talbot, M. R. \& Kling, G. W. Multiple stressors cause rapid ecosystem change in Lake Victoria. Freshw. Biol. 55, 19-42 (2010).

65. Drake, J. M. \& Lodge, D. M. Global hot spots of biological invasions: evaluating options for ballast-water management. Proc. R. Soc. Lond. B 271, 575-580 (2004).

66. Albright, R. et al. Reversal of ocean acidification enhances net coral reef calcification. Nature 531, 362-365 (2016)

67. Doney, S. C. et al. Climate change impacts on marine ecosystems. Ann. Rev. Mar. Sci. 4, 11-37 (2012)

68. Parr, C. L., Lehmann, C. E. R., Bond, W. J., Hoffmann, W. A. \& Andersen, A. N. Tropical grassy biomes: misunderstood, neglected, and under threat. Trends Ecol. Evol. 29, 205-213 (2014).

69. Stevens, N., Lehmann, C. E. R., Murphy, B. P. \& Durigan, G. Savanna woody encroachment is widespread across three continents. Glob. Chang. Biol. 23, 235-244 (2017)

70. McDowell, N. et al. Drivers and mechanisms of tree mortality in moist tropical forests. New Phytol. (2018).

71. Williams, J. W., Jackson, S. T. \& Kutzbach, J. E. Projected distributions of novel and disappearing climates by 2100 AD. Proc. Natl Acad. Sci. USA 104, 5738-5742 (2007).

72. Mahlstein, I., Knutti, R., Solomon, S. \& Portmann, R. W. Early onset of 
significant local warming in low latitude countries. Environ. Res. Lett. 6 , 034009 (2011).

73. Pecl, G. T. et al. Biodiversity redistribution under climate change: impacts on ecosystems and human well-being. Science 355, eaai9214 (2017).

74. Yamano, H., Sugihara, K. \& Nomura, K. Rapid poleward range expansion of tropical reef corals in response to rising sea surface temperatures. Geophys. Res. Lett. 38, L04601 (2011).

75. Wernberg, T. et al. Climate-driven regime shift of a temperate marine ecosystem. Science 353, 169-172 (2016)

76. Moore, R. P., Robinson, W. D., Lovette, I. J. \& Robinson, T. R. Experimenta evidence for extreme dispersal limitation in tropical forest birds. Ecol. Lett. 11 960-968 (2008).

77. VanDerWal, J. et al. Focus on poleward shifts in species' distribution underestimates the fingerprint of climate change. Nat. Clim. Chang. 3 239-243 (2013).

78. Hoffmann, A. A. \& Sgrò, C. M. Climate change and evolutionary adaptation. Nature 470, 479-485 (2011).

79. Hughes, T. P. et al. Spatial and temporal patterns of mass bleaching of corals in the Anthropocene. Science 359, 80-83 (2018).

80. Jensen, M. P. et al. Environmental warming and feminization of one of the largest sea turtle populations in the world. Curr. Biol. 28, 154-159 (2018).

81. Woodroffe, R., Groom, R. \& McNutt, J. W. Hot dogs: high ambient temperatures impact reproductive success in a tropical carnivore. J. Anim. Ecol. 86, 1329-1338 (2017)

82. Castello, L. \& Macedo, M. N. Large-scale degradation of Amazonian freshwater ecosystems. Glob. Chang. Biol. 22, 990-1007 (2016).

83. Brawn, J. D., Benson, T. J., Stager, M., Sly, N. D. \& Tarwater, C. E. Impacts of changing rainfall regime on the demography of tropical birds. Nat. Clim. Chang 7, 133-136 (2017)

84. Côté, I. M., Darling, E. S. \& Brown, C. J. Interactions among ecosystem stressors and their importance in conservation. Proc. R. Soc. Lond. B 283, 20152592 (2016)

85. Vinebrooke, R. D. et al. Impacts of multiple stressors on biodiversity and ecosystem functioning: the role of species co-tolerance. Oikos 104, 451-457 (2004).

86. Vega Thurber, R. L. et al. Chronic nutrient enrichment increases prevalence and severity of coral disease and bleaching. Glob. Chang. Biol. 20, 544-554 (2014).

87. Taylor, B. W., Flecker, A. S. \& Hall, R. O. Jr. Loss of a harvested fish species disrupts carbon flow in a diverse tropical river. Science 313, 833-836 (2006).

88. McClanahan, T. R. et al. Critical thresholds and tangible targets for ecosystembased management of coral reef fisheries. Proc. Natl Acad. Sci. USA 108, 17230-17233 (2011).

89. Graham, N. A. J., Jennings, S., MacNeil, M. A., Mouillot, D. \& Wilson, S. K Predicting climate-driven regime shifts versus rebound potential in coral reefs. Nature 518, 94-97 (2015).

90. Waldram, M. S., Bond, W. J. \& Stock, W. D. Ecological engineering by a mega-grazer: white rhino impacts on a south african savanna. Ecosystems 11 101-112 (2008).

91. Veldman, J. W. \& Putz, F. E. Grass-dominated vegetation, not species-diverse natural savanna, replaces degraded tropical forests on the southern edge of the Amazon Basin. Biol. Conserv. 144, 1419-1429 (2011).

92. Hughes, T. P. et al. Coral reefs in the Anthropocene. Nature 546, 82-90 (2017).

93. Phillips, O. L. et al. Increasing dominance of large lianas in Amazonian forests. Nature 418, $770-774$ (2002).

94. Harrison, R. D. et al. Consequences of defaunation for a tropical tree community. Ecol. Lett. 16, 687-694 (2013).

95. Hughes, T. P. Catastrophes, phase shifts and large-scale degradation of a Caribbean coral reef. Science 265, 1547-1551 (1994).

96. Mumby, P. J., Hastings, A. \& Edwards, H. J. Thresholds and the resilience of Caribbean coral reefs. Nature 450, 98-101 (2007)

97. Hicks, C. C., Crowder, L. B., Graham, N. A. J., Kittinger, J. N. \& Le Cornu, E. Social drivers forewarn of marine regime shifts. Front. Ecol. Environ. 14, 252-260 (2016).

98. Cinner, J. E. et al. Linking social and ecological systems to sustain coral reef fisheries. Curr. Biol. 19, 206-212 (2009).

99. O'Neill, D. W., Fanning, A. L., Lamb, W. F. \& Steinberger, J. K. A good life for all within planetary boundaries. Nat. Sustain. 1, 88-95 (2018).

100. Stern, D. I., Common, M. S. \& Barbier, E. B. Economic growth and environmental degradation: the environmental Kuznets curve and sustainable development. World Dev. 24, 1151-1160 (1996).

101. Alamgir, M. et al. Economic, socio-political and environmental risks of road development in the tropics. Curr. Biol. 27, R1130-R1140 (2017).

102. Deininger, K. \& Byerlee, D. Rising Global Interest in Farmland (The World Bank, Washington, D.C., 2011).

103. Laurance, W. F., Sayer, J. \& Cassman, K. G. Agricultural expansion and its impacts on tropical nature. Trends Ecol. Evol. 29, 107-116 (2014).

104. Pauly, D. On Malthusian overfishing. Naga, the ICLARM Quarterly 13, 3-4 (1990).

105. Rands, M. R. W. et al. Biodiversity conservation: challenges beyond 2010. Science 329, 1298-1303 (2010).

106. Blasiak, R. \& Wabnitz, C. C. C. Aligning fisheries aid with international development targets and goals. Mar. Policy 88, 86-92 (2018).

107. Mora, C. et al. Management effectiveness of the world's marine fisheries. PLoS 142. Biol. 7, e1000131 (2009).
108. Mammides, C. et al. Increasing geographic diversity in the international conservation literature: a stalled process? Biol. Conserv. 198, 78-83 (2016).

109. Lovejoy, T. E. \& Nobre, C. Amazon tipping point. Sci. Adv. 4, eaat2340 (2018)

110. Nilsson, M. Important Interactions among the Sustainable Development Goals Under Review at the High-Level Political Forum 2017 (SEI, Stockholm, 2017).

111. Kopnina, H., Washington, H., Gray, J. \& Taylor, B. The 'future of conservation' debate: defending ecocentrism and the Nature Needs Half movement. Biol. Conserv. 217, 140-148 (2018).

112. UNEP-WCMC \& IUCN. Protected Planet: the World Database on Protected Areas (WDPA) (2018)

https://www.protectedplanet.net/c/world-database-on-protected-areas

113. Watson, J. E. M., Dudley, N., Segan, D. B. \& Hockings, M. The performance and potential of protected areas. Nature 515, 67-73 (2014).

114. Büscher, B. et al. Half-Earth or Whole Earth? Radical ideas for conservation, and their implications. Oryx 51, 407-410 (2017).

115. Symes, W. S., Rao, M., Mascia, M. B. \& Carrasco, L. R. Why do we lose protected areas? Factors influencing protected area downgrading, downsizing and degazettement in the tropics and subtropics. Glob. Chang. Biol. 22, 656-665 (2016)

116. Agrawal, A., Nepstad, D. \& Chhatre, A. Reducing emissions from deforestation and forest degradation. Annu. Rev. Environ. Resour. 36, 373-396 (2011).

117. Winder, G. M. \& Le Heron, R. Assembling a Blue Economy moment? Geographic engagement with globalizing biological-economic relations in multi-use marine environments. Dialogues Hum. Geogr. 7, 3-26 (2017).

118. Lambin, E. F. et al. The role of supply-chain initiatives in reducing deforestation. Nat. Clim. Chang. 8, 109-116 (2018).

119. Carlson, K. M. et al. Effect of oil palm sustainability certification on deforestation and fire in Indonesia. Proc. Natl Acad. Sci. USA 115, 121-126 (2018).

120. Richards, R. C. et al. Governing a pioneer program on payment for watershed services: stakeholder involvement, legal frameworks and early lessons from the Atlantic forest of Brazil. Ecosyst. Serv. 16, 23-32 (2015).

121. Kosoy, N. \& Corbera, E. Payments for ecosystem services as commodity fetishism. Ecol. Econ. 69, 1228-1236 (2010).

122. Corbera, E. \& Schroeder, H. REDD+ crossroads post Paris: Politics, lessons and interplays. Forests 8, 508 (2017).

23. Liu, J. et al. Systems integration for global sustainability. Science $\mathbf{3 4 7}$, 1258832-1258832 (2015).

124. Cinner, J. E. et al. Comanagement of coral reef social-ecological systems. Proc. Natl Acad. Sci. USA 109, 5219-5222 (2012).

125. Porter-Bolland, L. et al. Community managed forests and forest protected areas: an assessment of their conservation effectiveness across the tropics. For. Ecol. Manage. 268, 6-17 (2012)

126. Gudynas, E. Buen Vivir: today's tomorrow. Development 54, $441-447$ (2011)

127. Seymour, F. \& Busch, J. Why Forests? Why Now? The Science, Economics, and Politics of Tropical Forests and Climate Change (Center for Global Development, Washington, D.C., 2016).

128. Mace, G. M. Whose conservation? Science 345, 1558-1560 (2014).

129. Soulé, M. in Keeping the Wild: Against the Domestication of Earth (eds Wuerthner, G. et al.) 66-80 (Island, Washington, D.C., 2014).

130. Holmes, G., Sandbrook, C. \& Fisher, J. A. Understanding conservationists' perspectives on the new-conservation debate. Conserv. Biol. 31, 353-363 (2017).

131. Matulis, B. S. \& Moyer, J. R. Beyond inclusive conservation: the value of pluralism, the need for agonism, and the case for social instrumentalism. Conserv. Lett. 10, 279-287 (2017).

132. Montesino Pouzols, F. et al. Global protected area expansion is compromised by projected land-use and parochialism. Nature 516, 383-386 (2014).

133. Larsen, R. K. et al. Hybrid governance in agricultural commodity chains: insights from implementation of 'No Deforestation, No Peat, No Exploitation' (NDPE) policies in the oil palm industry. J. Clean. Prod. 183, 544-554 (2018).

134. Winemiller, K. O. et al. Balancing hydropower and biodiversity in the Amazon, Congo, and Mekong. Science 351, 128-129 (2016).

135. van Oppen, M. J. H., Oliver, J. K., Putnam, H. M. \& Gates, R. D. Building coral reef resilience through assisted evolution. Proc. Natl Acad. Sci. USA 112, 2307-2313 (2015).

136. Svenning, J.-C. et al. Science for a wilder Anthropocene: synthesis and future directions for trophic rewilding research. Proc. Natl Acad. Sci. USA 113 898-906 (2016)

137. Hortal, J. et al. Seven shortfalls that beset large-scale knowledge of biodiversity. Annu. Rev. Ecol. Evol. Syst. 46, 523-549 (2015).

138. DRYFLOR et al. Plant diversity patterns in Neotropical dry forests and their conservation implications. Science 353, 1383-1387 (2016).

139. Leal, C. G. et al. Is environmental legislation conserving tropical stream faunas? A large-scale assessment of local, riparian and catchment-scale influences on Amazonian fish. J. Appl. Ecol. 55, 1312-1326 (2018).

140. Pitman, N. C. A., Azáldegui, M. d. C. L., Salas, K., Vigo, G. T. \& Lutz, D. A. Written accounts of an Amazonian landscape over the last 450 years. Conserv. Biol. 21, 253-262 (2007)

141. Feeley, K. Are we filling the data void? An assessment of the amount and extent of plant collection records and census data available for tropical South America. PLoS ONE 10, e0125629 (2015).

Sutherland, W. J., Gardner, T. A., Haider, L. J. \& Dicks, L. V. How can local and traditional knowledge be effectively incorporated into international assessments? Oryx 48, 1-2 (2014). 
143. Ghazoul, J. \& Chazdon, R. Degradation and recovery in changing forest landscapes: a multiscale conceptual framework. Annu. Rev. Environ. Resour. 42 161-188 (2017).

144. Liu, J. et al. Framing sustainability in a telecoupled world. Ecol. Soc. 18, art26 (2013).

145. Brashares, J. S. Bushmeat hunting, wildlife declines, and fish supply in West Africa. Science 306, 1180-1183 (2004).

146. Daskin, J. H. \& Pringle, R. M. Warfare and wildlife declines in Africa's protected 165 areas. Nature 553, 328-332 (2018).

147. Richards, P. D., Myers, R. J., Swinton, S. M. \& Walker, R. T. Exchange rates, soybean supply response, and deforestation in South America. Glob. Environ. Change 22, 454-462 (2012).

148. Hicks, C. C. et al. Engage key social concepts for sustainability. Science 352, 38-40 (2016).

149. Fischer, J. et al. Advancing sustainability through mainstreaming a socialecological systems perspective. Curr. Opin. Environ. Sustain. 14, 144-149 (2015).

150. Cvitanovic, C. et al. Improving knowledge exchange among scientists and decision-makers to facilitate the adaptive governance of marine resources: a review of knowledge and research needs. Ocean Coast. Manage. 112, 25-35 (2015).

151. Cinner, J. E. et al. Bright spots among the world's coral reefs. Nature 535 , 416-419 (2016).

152. Bennett, E. M. et al. Bright spots: seeds of a good Anthropocene. Front. Ecol. Environ. 14, 441-448 (2016).

153. Pringle, R. M. Upgrading protected areas to conserve wild biodiversity. Nature 546, 91-99 (2017).

154. Balvanera, P. et al. Key features for more successful place-based sustainability research on social-ecological systems: a Programme on Ecosystem Change and Society (PECS) perspective. Ecol. Soc. 22, 14 (2017).

155. Clarke, D. A., York, P. H., Rasheed, M. A. \& Northfield, T. D. Does biodiversityecosystem function literature neglect tropical ecosystems? Trends Ecol. Evol. 32, 320-323 (2017).

156. Gardner, T. A. et al. A social and ecological assessment of tropical land uses at multiple scales: the Sustainable Amazon Network. Phil. Trans. R. Soc. B 368 20120166 (2013).

157. Rose, R. A. et al. Ten ways remote sensing can contribute to conservation Conserv. Biol. 29, 350-359 (2015).

158. Thomsen, P. F. \& Willerslev, E. Environmental DNA - an emerging tool in conservation for monitoring past and present biodiversity. Biol. Conserv. 183, 4-18 (2015).

159. Gardner, T. A. et al. Transparency and sustainability in global commodity supply chains. World Dev. (2018).

160. Basset, Y. et al. Conservation and biological monitoring of tropical forests: the role of parataxonomists. J. Appl. Ecol. 41, 163-174 (2004).

161. Barlow, J. et al. Using learning networks to understand complex systems: a case study of biological, geophysical and social research in the Amazon. Biol. Rev. Camb. Philos. Soc. 86, 457-474 (2011).
162. Barlow, J. et al. On the extinction of the single-authored paper: the causes and consequences of increasingly collaborative applied ecological research. J. Appl. Ecol. 55, 1-4 (2018).

163. Dinerstein, E. et al. An ecoregion-based approach to protecting half the terrestrial realm. Bioscience 67, 534-545 (2017).

164. Kleypas, J. A., McManus, J. W. \& Meñez, L. A. B. Environmental limits to coral reef development: where do we draw the line? Am. Zool. 39, 146-159 (1999).

Birdlife International \& Handbook of the Birds of the World. Bird species distribution maps of the world Version 7.0 (2017).

http://datazone.birdlife.org/species/requestdis

166. Tedesco, P. A. et al. A global database on freshwater fish species occurrence in drainage basins. Sci. Data 4, 170141 (2017).

167. Cochrane, M. A. Fire science for rainforests. Nature 421, 913-919 (2003).

168. Flores, B. M., Fagoaga, R., Nelson, B. W. \& Holmgren, M. Repeated fires trap Amazonian blackwater floodplains in an open vegetation state. J. Appl. Ecol. 53, 1597-1603 (2016)

169. Jolly, W. M. et al. Climate-induced variations in global wildfire danger from 1979 to 2013. Nat. Commun. 6, 7537 (2015).

170. Durigan, G. \& Ratter, J. A. The need for a consistent fire policy for Cerrado conservation. J. Appl. Ecol. 53, 11-15 (2016).

Acknowledgements We thank the following for providing data: Birdlife International, International Union for Conservation of Nature, Ocean Biogeographic Information System, C. Veron for zooxanthellate corals, the Large-Scale Biosphere-Atmosphere Program (LBA) and National Environment Research Council grant NE/P004512/1 for forest birds, John Fell Fund for savannah birds, Pew Marine Fellows Program of The Pew Charitable Trusts, and Brazilian Council for Scientific and Technological Development (CNPq) (PELD 441659/2016-0). Individual funding was provided by National Environment Research Council NE/ 016431/1; NE/P004512/1; NE/L000016/1; European Research Council 759457; H2020-MSCA-RISE (691053-ODYSSEA); NASA's Interdisciplinary Research in Earth Sciences program (NNX14AD29G); OIST and JSPS KAKENHI (JP17K15180); CNPq scientific productivity grant (307788/2017-2); CNPq Programa de Capacitação Institucional (300231/2016-4); Royal Society (UF140691) and Swedish Research Council Formas grant (2016-00351).

Author contributions J.B. developed the review with input from N.A.J.G., T.A.G., C.C.H., A.C.L. and J.F. F.F. and G.D.L. analysed the data, supported by J.B., T.A.G., C.C.H., E.B., L.C., E.P.E., B.G., C.G.L., V.I., A.C.L., C.L.P., S.K.W., P.J.Y. and N.A.J.G. J.B., T.A.G., C.C.H., N.A.J.G., L.C., A.C.L., C.L.P., F.F. and G.D.L. wrote the manuscript with input from all authors.

Correspondence and requests for materials should be addressed to J.B. (josbarlow@gmail.com) 